\title{
"Which resources matter the most to firm performance? An experimental study on Malaysian listed firms"
}

\begin{tabular}{|c|c|}
\hline & $\begin{array}{l}\text { Omar Masood } \\
\text { Bora Aktan (D) https://orcid.org/0000-0002-1334-3542 }\end{array}$ \\
\hline AUTHORS & $\begin{array}{l}\text { Seref Turen } \\
\text { Kiran Javaria } \\
\text { Mohamed Sayed Abou EISeoud }\end{array}$ \\
\hline ARTICLE INFO & $\begin{array}{l}\text { Omar Masood, Bora Aktan, Seref Turen, Kiran Javaria and Mohamed Sayed } \\
\text { Abou EISeoud (2017). Which resources matter the most to firm performance? An } \\
\text { experimental study on Malaysian listed firms . Problems and Perspectives in } \\
\text { Management, 15(2), 74-80. doi:10.21511/ppm.15(2).2017.07 }\end{array}$ \\
\hline DOI & http://dx.doi.org/10.21511/ppm.15(2).2017.07 \\
\hline RELEASED ON & Wednesday, 07 June 2017 \\
\hline RECEIVED ON & Friday, 10 February 2017 \\
\hline \multirow[t]{2}{*}{ ACCEPTED ON } & Monday, 13 March 2017 \\
\hline & $(\mathrm{cc}) \mathrm{EY}$ \\
\hline LICENSE & $\begin{array}{l}\text { This work is licensed under a Creative Commons Attribution } 4.0 \text { International } \\
\text { License }\end{array}$ \\
\hline JOURNAL & "Problems and Perspectives in Management" \\
\hline ISSN PRINT & $1727-7051$ \\
\hline ISSN ONLINE & $1810-5467$ \\
\hline PUBLISHER & LLC "Consulting Publishing Company "Business Perspectives" \\
\hline FOUNDER & LLC "Consulting Publishing Company "Business Perspectives" \\
\hline
\end{tabular}

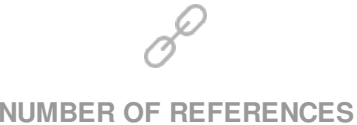

27
NUMBER OF FIGURES

1
NUMBER OF TABLES

3

(c) The author(s) 2023. This publication is an open access article. 


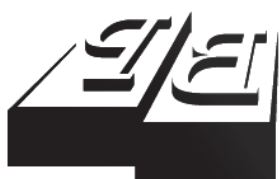

BUSINESS PERSPECTIVES

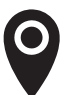

LLC "CPC "Business Perspectives" Hryhorii Skovoroda lane, 10, Sumy, 40022, Ukraine

www.businessperspectives.org

Received on: $18^{\text {th }}$ of January, 2017 Accepted on: $26^{\text {th }}$ of February, 2017

(C) Omar Masood, Bora Aktan, Seref Turen, Kiran Javaria, Mohamed Sayed Abou ElSeoud, 2017

Omar Masood, Quaid-i-Azam School of Management Sciences, Quaid-i-Azam University, Islamabad, Pakistan.

Bora Aktan, College of Business Administration, Sakheer Campus, University of Bahrain, Kingdom of Bahrain; Faculty of Commerce and Business Administration, Future University in Egypt, New Cairo, Egypt.

Seref Turen, College of Business Administration, Sakheer Campus, University of Bahrain, Kingdom of Bahrain.

Kiran Javaria, Quaid-i-Azam School of Management Sciences, Quaidi-Azam University, Islamabad, Pakistan.

Mohamed Sayed Abou ElSeoud, College of Business Administration, Sakheer Campus, University of Bahrain, Kingdom of Bahrain.

\section{(ㄷ)(1)}

This is an Open Access article, distributed under the terms of the Creative Commons Attribution 4.0 International license, which permits unrestricted re-use, distribution, and reproduction in any medium, provided the original work is properly cited.
Omar Masood (Pakistan), Bora Aktan (Kingdom of Bahrain), Seref Turen (Kingdom of Bahrain), Kiran Javaria (Pakistan), Mohamed Sayed Abou ElSeoud (Kingdom of Bahrain)

\section{WHICH RESOURCES MATTER THE MOST TO FIRM PERFORMANCE? AN EXPERIMENTAL STUDY
ON MALAYSIAN LISTED FIRMS}

\begin{abstract}
This study investigates the impact of various resources, specifically both tangible and intangible ones, together with capabilities of Malaysian listed firms, on their performance. This empirical study attempts to enrich the understanding of the resourcesperformance relationship, which is one of a business process within the firm, as well as filling the gaps in present knowledge. Firms, which are not able to develop and sustain their performance, are associated with the vulnerability and adverse performance result, especially during various periods of economic crisis (three sub-periods of major shocks, i.e., The Volcker Shock (Commodities Shock) of early 1980s, Asian Financial Crisis of the late 1990s, and the Global Financial Meltdown of 2008). Hence, this research intends to explore which resources matter the most to firm profitability and its success. Drawing upon the combination of Donabedian's structure process outcome and resource-based theories of the firm a conceptual framework is developed. Data for the study were collected from a sample of 250 publicly traded companies listed on Bursa Malaysia (MYX). In order to achieve the objective and response to the study question, partial least square and regression analysis are applied. Findings indicate that tangible resources have no impact, while intangible resources have positive and significant impact on firm performance. In addition, results show that efficient allocation of intangible resources is crucial to achieving good performance.
\end{abstract}

Keywords

tangible and intangible resources, resource-based theory, firm performance, Donabedian's structure process outcome theory, Malaysia

JEL Classification G10, G12, L25

\section{INTRODUCTION}

Crisis after crisis has raised questions about the sustainability performance and resilience of the firm in the event of an adverse market environment. Three sub-periods (1985-1986, 1997-1998 and 2008-2009) during which the economy of Malaysia was subjected to major shocks have, indeed, become bitter lessons, which have broad relevance for the firms to strengthen their corporate financial structure that was too weak to withstand the combined shocks of increased interest rates, devalued currencies, and sharp declines in domestic demand (Stijn Claessens, Djankov, \& Xu, 2000). Malaysia is striving to achieve sustainable economic development where knowledge and know-how become the main drivers of economic growth (Majlis Inovasi Negara, 2007). Firm resources, particularly intangible resources, helps nations to shift from a traditional in- 
dustrial economy to a knowledge-based economy (Mustapha \& Abdullah, 2004). This study partially adopted the theory of structure, process outcome theory (also known as Donabedian theory), which encompasses the relationship between structure, process, and outcome in an organization and partially adopted the resource-based theory, which has clear articulation on the dimension of firm-specific or firm resources. Specifically, the main aim of the study is to examine the effect of each component of firm resources on firm performance.

\section{PREVIOUS STUDIES}

\subsection{Theoretical background}

This study follows and developed the concept established by resource-based view theory (RBV) and Donabedian theory with the expressed purpose of attempting strategic management into a more comprehensive model. Donabedian (1966 \& 1988) posits in his study that the relationship and dimension of structure of an organization interconnected with process and outcome of the organization, which lead to the introduction of structure process outcome theory (SPO). The structure process outcome theory also widely is known as Donabedian theory. This renowned theory in health care referred to the hospital management setting, the attributes mentioned in his study referring to material resources, human resources, and organizational resources, respectively. Donabedian's, (1988) study employed only tangible setting and facilities as dimension under its structure construct, this study uses a widely developed, multidimensional construct of firm resources under resource-based theory to be incorporated within this study framework. According to resource-based theory, resources are generally classified as tangible or intangible (Galbreath, 2005). R. Hall (1992) is one of the few studies that specifically defined and specified clear dimension on firm resources. He postulates that the resources of the firm can be divided into two: tangible and intangible resources, from which the latter can be categorized into assets and skills (capabilities). Using a multidimensional representation of the firm resources by Fahy (2002) and Galbreath \& Galvin (2008), this research builds upon Barney's (1991) initial efforts to establish the links between firm resources and firm performance by adopting the RBV theory and incorporating it with Donabedian theory to build upon the research framework of this study.

\subsection{Relationship analysis of firm resources and performance}

\subsubsection{Influence of intangible resources on firm performance}

The RBV perceives the firm as a unique bundle of idiosyncratic resources and capabilities, where the primary task of management is to maximize value through the optimal deployment of existing resources and capabilities while developing the firm's resource base for the future. Hall (1992) analyzes the relative importance of intangible resources to firm success and suggests the importance of intangible resources in contributing to firm success among both manufacturing and services firms, with the exception of one tangible resource (which is not defined or explained), only intangible resources are studied, thereby eliminating the observation of other resources - namely tangible resources - that may be potential determinants of firm success otherwise. Furthermore, although serving as a practical guide for future research, Hall's (1992) study lacks theoretical grounding and statistical rigor (e.g., psychometric evaluation of constructs, tests of significance). In a follow up to his 1992 study, Hall (1993) further explores the impact of various intangible resources on firm success. As with the 1992 study, the intangible resources deemed most important to firm success are: 1) company reputation; 2) product reputation; 3) employee know-how; 4) perception of quality standards (an attribute of organizational culture); and 5) ability to manage change (an attribute of organizational culture). Hall (1993) confirms the findings of his previous study, which is important from the viewpoint of replicability and generalizability. Powell and Dent-Micallef (1997) study three resources constructs, namely, information technology, and the complementariness of human and business resources. The results indicate that for overall firm performance, human resources have a positive and zero-order correlation, business resources have a moderate correlation, and technology resources 


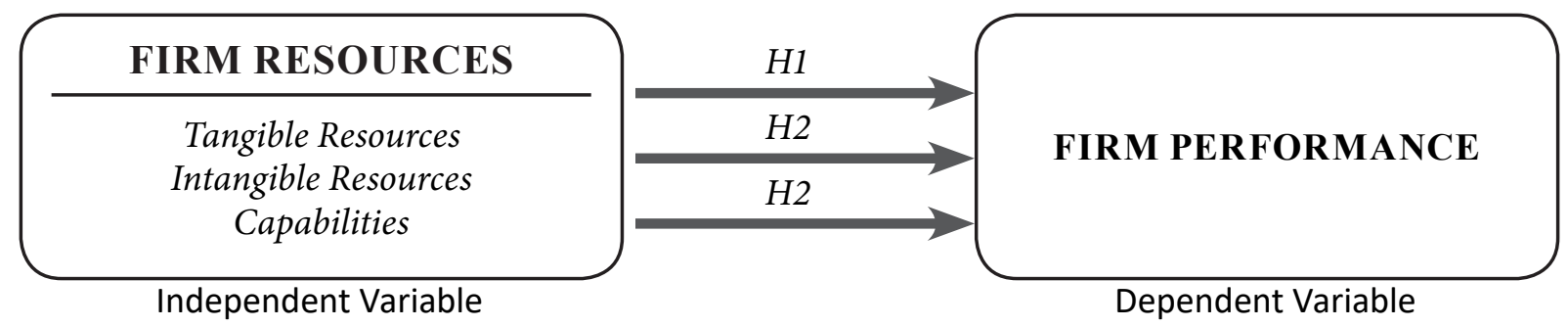

Figure 1. Hypothesized research model

have a negative, but non-significant correlation. The results of this study seem to indicate the importance of intangible resources in positively impacting firm success.

H1: There is a positive and significant impact of intangible resources on firm performance.

\subsubsection{Influence of tangible resources on firm performance}

Firms can use a variety of tangible and intangible resources and assets to build organizational competencies. A working definition of 'competitive advantage' itself is controversial (Foss and Knudsen, 2003; Powell, 2001), but such a concept is directly unobservable so that empirical tests normally involve seeking to explain inter-firm differences in performance (Peteraf and Barney, 2003). Sustainable competitive advantage, however, requires that the condition of heterogeneity or differentiation among firms be preserved. While tangible assets may create competitive advantages, such advantages are unlikely to be sustained, since tangible assets may be bought and sold in market transactions at prices equal to their economic value (Galbreath, 2005b). Scholars (see, for example, Foss, 1997; Lippman and Rumelt, 2003) suggest that tangible resources may be sources of competitive advantage. Foss (1997) argues that there are many examples of firms having attained, and sustained, competitive advantage by means of tangible resources. Furthermore, Makhija (2003) suggests that it is entirely possible that tangible resources can be sources of above-normal returns. Recognizing a limitation of his study, Carmeli (2001), for example, implies that tangible resources should be included in RBV research. In a final study, modelled on Fahy (2002), Galbreath (2004a) studies the importance of intellectual property assets, organizational assets, reputational assets, and capabilities to firm success, relative to tangible assets. In the management literature, the resource-based view of a firm claims that firms compete on the basis of "unique" corporate resources that are valuable, rare, difficult to imitate, and non-substitutable by competitors (Hassan Elnaby et al., 2012; Barney, 1991). These unique resources enable firms to achieve competitive advantage and superior long-term performance. In addition to that, the findings from Meulbroek (2002) and Altuntas, Berry-Stoelzle, and Hoyt (2011) argue that poor allocation of tangible resources also contributed to the poor corporate performance in terms of dealing with capital efficiency and return on equity.

\section{H2: There is a positive and significant impact of tangible resources on firm performance. \\ 1.2.3. Influence of capabilities on firm performance}

According to the RBV, resources are generally classified as tangible or intangible (Galbreath, 2005). R. Hall (1992) is one of the few studies that specifically defined and specified clear dimension on firm resources. He postulates that the resources of the firm can be divided into two: tangible and intangible resources, from which the latter can be categorized into assets and skills (capabilities). The work of GU and Guan (2005) also supports the finding of the above study, which emphasizes that firm's resources and capabilities are more influential in determining their firm performance. HassabElnaby, Hwang, and Vonderembse (2012) proposed that organizational capabilities are a firm's abilities to perform a set of tasks using company resources. Firms develop and manage organizational capabilities in order to gain competitive advantage by engendering an organization categorical competency. According to Galbreath (2004a) studies, the importance of intellectual property assets, organizational assets, reputational assets, and capabilities to firm success, are relative resources of any organization. No statistically significant differences are found between IPA and tangible assets. Lastly, capabilities are statistically more important 
to firm success than both tangible and intangible assets. Fahy (2002) also tests the impact of resources on low-performing versus high-performing firms using discriminant analysis. Top-performing firms ascribe significantly higher levels of importance to firm-specific capabilities (intangible resources) than low-performing firms.

\section{H3: There is a positive and significant impact of firm capabilities on its performance.}

On the bases of existing literature and the theory, the following model is developed. In the model, firm resources, which are tangible assets, intangible assets and capabilities are independent variables and firm performance is dependent variable as shown below:

\section{METHODOLOGY}

\subsection{Statistical tool}

Structural equation modeling was used in this study. SEM offers a comprehensive and systematic analysis that helps researchers to answer a set of interrelated research questions (Gefen, Straub, \& Boudreau, 2000). Partial least square (PLS) is employed to examine the hypotheses of this research as it is capable to tackle a set of interrelated questions with one comprehensive method. The basic function of the outer model is to assess the goodness of the measures used in this study through reliability and validity of the constructs. There are two types of models in SEM: the structural model and the measurement models. The measurement models come in two sub-types: reflective measurement models and formative measurement models. These models are assessed against the following aspects: indicator reliability, internal consistency reliability, convergent validity, and discriminant validity. Hence, it can be observed, measuring a particular construct loaded highly on that construct and loaded lower on the other constructs, thus, confirming validity. There is no common method bias. Reliability analysis shows that all items were consistent and reliable in nature. Here all variable Cronbach's Alpha value was greater than 0.6, which shows that all items were reliable. All variables skewness and kurtosis value lies between -3 to +3 and -10 to +10 , respectively, which shows that data were normally distributed.

\subsection{Data}

Compilation of data for this research engaged both the assembly of primary and secondary data. The gathering of primary data is through questionnaire survey and secondary data gathered through literature review comprising relationship between firm resources and firm performance. Statistical studies were used in the research to verify if firm performance is dependent on factors, such as firm resources. This strategy permits a large amount of quantitative data to be collected from a population, which, then, can be analyzed using descriptive and inferential statistics (Saunders et al., 2009). Data for the study were collected from a sample of public listed companies on Malaysian Bursa. There were 930 companies in main market and 130 companies in ACE market, which stands for Access, Certainty, Efficiency. And of these 250 companies were selected for the study. The process of sample selection is called sampling design and this study employs the use of judgment sampling, which involves the choice of subjects who are most advantageously placed or in the best position to provide the information required. The rule of thumb is an acceptable level for response rate of 30 percent (Sekaran, 2013), hence, the 223 responses were deemed usable for further analysis.

Table 1. Demographic analysis

\begin{tabular}{|c|c|c|}
\hline Demographic characteristics & Frequency & $\%$ \\
\hline \multicolumn{3}{|l|}{ Age: } \\
\hline Below 30 & 34 & 15.20 \\
\hline $31-40$ & 95 & 42.60 \\
\hline $41-45$ & 60 & 26.90 \\
\hline $46-50$ & 28 & 12.60 \\
\hline Above 50 & 6 & 2.70 \\
\hline Total & 223 & 100 \\
\hline \multicolumn{3}{|c|}{ Gender: } \\
\hline Male & 116 & 52.0 \\
\hline Female & 107 & 48.0 \\
\hline Total & 223 & 100 \\
\hline \multicolumn{3}{|c|}{ Working experience: } \\
\hline Below 5 years & 32 & 14.3 \\
\hline $6-10$ years & 29 & 13.0 \\
\hline More than 10 years & 162 & 72.6 \\
\hline Total & 223 & 100 \\
\hline
\end{tabular}


Table 1 (cont). Demographic analysis

\begin{tabular}{|c|c|c|}
\hline Demographic characteristics & Frequency & $\%$ \\
\hline \multicolumn{3}{|c|}{ Education level: } \\
\hline Doctoral & 11 & 4.90 \\
\hline Masters & 68 & 30.50 \\
\hline Bachelor degree/Advance diploma & 100 & 44.80 \\
\hline Diploma & 44 & 19.70 \\
\hline Total & 223 & 100 \\
\hline \multicolumn{3}{|c|}{ Education background: } \\
\hline Engineering/Production & 53 & 23.80 \\
\hline Finance/Accounting & 35 & 15.70 \\
\hline Marketing/Sales & 24 & 10.80 \\
\hline Economic/Business & 52 & 23.30 \\
\hline Human Resource management & 8 & 3.60 \\
\hline Architecture & 3 & 1.30 \\
\hline Science/Technology & 28 & 12.60 \\
\hline Others & 20 & 9.00 \\
\hline Total & 223 & 100 \\
\hline
\end{tabular}

In sample of this study, majority of respondents were male. There were $52 \%$ male and $48 \%$ female respondents. Most respondents belonged to age group of 31-40 years. Most respondents' educational background was Engineering and Production, as their percentage was $24 \%$. Most respondents had work experience of more than 10 years and their percentage is $72 \%$ and mostly respondents' educational level is Bachelor Degree or advance diploma as its percentage is $44 \%$ which was higher than others.

\section{EMPIRICAL ANALYSIS}

\subsection{Structural model relationships assessments}

Table 2. Collinearity values among exogenous construct

\begin{tabular}{c|c:c|c}
\hline $\begin{array}{c}\text { Exogenous } \\
\text { constructs }\end{array}$ & $\begin{array}{c}\text { Endogenous } \\
\text { constructs }\end{array}$ & VIF & Tolerance \\
\hline TR & PERF & 1.226 & .815 \\
\hline IR & & 1.236 & .809 \\
\hdashline CAP & & 1.353 & .739 \\
\hline ERM & & 1.111 & .900 \\
\hline
\end{tabular}

Table 2 presents the VIF values and tolerance levels of all the exogenous constructs in the structural model. Results indicate that VIF values are below the recommended threshold value of 3.3 and the tolerance levels are greater than 0.20 indicating there are no significant levels of collinearity among the exogenous constructs (Hair et al., 2014).

Table 3. Path coefficients, observed t-statistics, and significance level for all hypothesized path

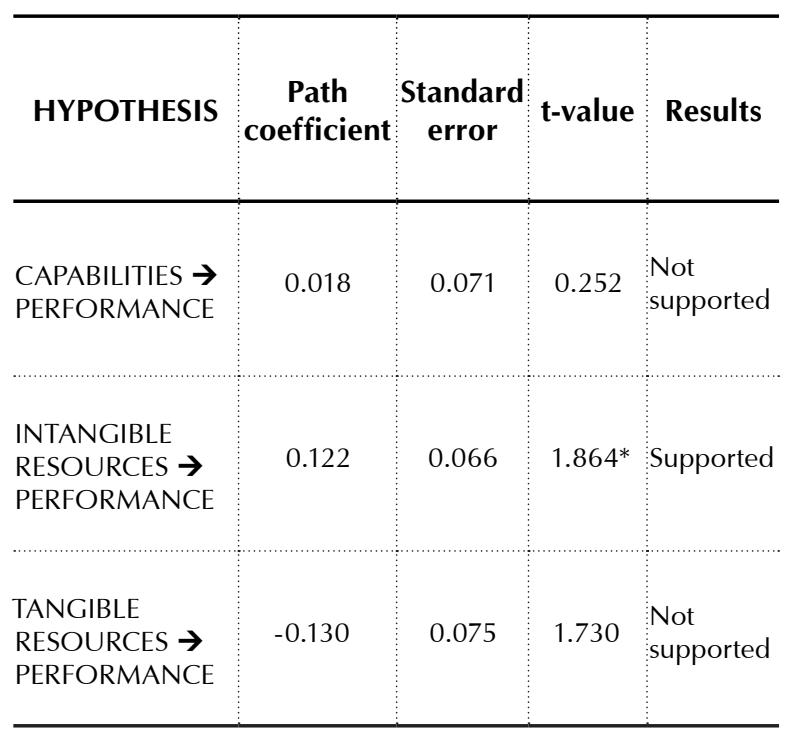

Note: $* \mathrm{t}$-values $>1.645(\mathrm{p}<0.05) ; * * \mathrm{t}$-values $>2.33(\mathrm{p}<0.01)$ (one-tailed test).

The path coefficient between TR, IR and CAP is comprised of mixed results, with the path coefficient between TR and PERF is no significant with $\beta=(-0.130)$ and $t$-value of 1.730 . Same goes to path coefficient of CAP and PERF, which has $\beta=0.018$ and $t-v a l u e=0.252$. As a result, hypotheses $\mathrm{H} 1$ and $\mathrm{H} 3$ are not supported. However, the path coefficient between IR and PERF is moderate with $\beta=0.122$ and $t$-value $=1.864$. As a result, hypothesis $\mathrm{H} 2$ is supported. Within the structural model, each path connecting two latent variables represented a hypothesis. Based on the analysis conducted on the structural model, it allows the researcher to confirm or disconfirm each hypothesis, as well as understand the strength of the relationship between dependent and independent variables. Using the SmartPLS algorithm output, the relationships between independent and dependent variables were examined. However, in SmartPLS, in order to test the significant level, $t$-statistics for all paths are generated using the SmartPLS bootstrapping 
function. Based on the t-statistics output, the significant level of each relationship is determined. Table 3 lists down the path coefficients, observed t-statistics, and significance level for all hypothesized path. Using the results from the path assessment, the acceptance or rejection of the proposed hypotheses is determined.

To validate the proposed hypotheses and the structural model, the path coefficient between two latent variables is assessed. Based on previous studies, the path coefficient value needs to be at least 0.1 to account for a certain impact within the model (Hair et al., 2011). Assessment of the path coefficient (see Table 3) shows that all proposed hypotheses are not supported, ex- cept for hypothesis 2 (H2). From the analysis, supported hypotheses are significant at least at the level of 0.05 , have expected sign directions (i.e., positive) and consist of a path coefficient value $(\beta)$ ranging from 0.122 to 0.653 .

After that, $\mathrm{R}$ square, $\mathrm{F}$ square and $\mathrm{Q}$ square tests are conducted. R2 is an important criterion for assessing the explanatory power of the structural model and should be calculated for each endogenous LV in the model. Tangible resources (TR), intangible resources (IR) and capabilities (CAP) are able to explain $47 \%$ of the variance in performance (PERF). F square value shows that CAP have a very small effect in producing R2 for PERF. Similarly, TR and IR also have small scale effect on the R2 of PERF.

\section{CONCLUSION}

The aim of the study is to find a relationship between firm resources and its performance. Hypotheses for the study are tested quantitatively. Data from 223 Malaysian listed companies were used for analysis. Statistical studies were used in the research to verify if firm performance is dependent on factors, such as tangible resources, intangible resources and capabilities relationship. The four variables involved in the study, namely tangible resources, intangible resources, capabilities and firm performance were measured using scales adapted from previous studies. The research framework proposed a significant relationship between tangible resources, intangible resources, capabilities, firm performance. Structural equation modelling was used to assess the framework. The analysis of the relationship between tangible resources, intangible resources, capabilities and firm performance showed that not all the resource factors had a significant effect on firm performance. Only one factor had a significant relationship on firm performance, namely, intangible resources.

Indicators under tangible resources such as financial investment and raised financial capital positively influenced firm performance. In summary, the finding of this study supports empirical evidence posits that not all resources dimensions are important drivers of performance. In the current business landscape, land, labor and many tangible assets are no longer significant to explain business performance. The concept of specific human capital plays vital roles within the nature of risk manager at the firm level. Human capital covers skills, knowledge, education, and experience of the managers and the key personnel in the organization. This study provides evidence that out of the three-dimensional context of intangible resources, only organizational asset and reputational asset are relevant and significant within Malaysia context. As such, the weight of evidence from most of the literature described above leads this study to conclude that firms should pay crucial attention to interconnectedness of their intangible and tangible resources, as it may improve their inner structure of resources deployment, which will influence the positive reaction towards its firm performance by concentrating more on combining resources that lead to the optimum deployment level, which contributes towards superior performance and competitive advantage. The hypotheses relating capabilities to the firm performance were not supported, as the structural path coefficient did not fall within the significant range. This study argues that capabilities are the most dominant resources, as this study shows and uses Malaysian listed firms sample and varies across industries. 


\section{REFERENCES}

1. Altuntas, M., Berry-Stoelzle, T. R., \& Hoyt, R. E. (2011). Implementation of Enterprise Risk Management: Evidence from the German Property-Liability Insurance Industry. Geneva Papers on Risk and Insurance-Issues and Practice, 36(3), 414-439. https://doi.org/10.1057/ gpp.2011.11

2. Barney, J. (1991). Firm Resources and Sustained Competitive Advantage. Journal of Management. https://doi. org/10.1177/014920639101700108

3. Carmeli, A., \& Tishler, A. (2004). The relationships between intangible organizational elements and organizational performance. Strategic Management Journal, 25(13), 1257-1278. https://doi. org/10.1002/smj.428

4. Claessens, S., Djankov, S., \& Xu, L (2000). Corporate performance in the East Asian financial crisis. The World Bank Research Observer, 15(1), 23-46. Retrieved from http:// wbro.oxfordjournals.org/content/15/1/23.short

5. Donabedian, A. (1966). The quality of care. How can it be assessed? JAMA: The Journal of the American Medical Association, 260(12), 17431748.

6. Donabedian, A. (1988). The quality of care: How can it be assessed? JAMA. Retrieved from http:// jama.jamanetwork.com/article. aspx?articleid=374139

7. Fahy, J. (2002). A resource-based analysis of sustainable competitive advantage in a global environment. International Business Review, 11(1), 57-77. https://doi.org/10.1016/ S0969-5931(01)00047-6

8. Foss, N. (1997). Market process economics and the theory of the firm. Beyond the boundaries of the firm: Intergrating theories of the firm and theories of the markets.

9. Foss, N. J., \& Knudsen, T. (2003). The Resource-Based Tangle: Towards a Sustainable Explanation of Competitive Advantage. Managerial and Decision Economics, 24(4), 291-307. https://doi. org/10.1002/mde.1122
10. Galbreath, J. (2005a). The intangible economy and firm superior performance: Evidence from Australia. Journal of Management and Organization, 11, 28-40. https:// doi.org/10.5172/jmo.2005.11.1.28

11. Galbreath, J. (2005b). Which resources matter the most to firm success? An exploratory study of resource-based theory. Technovation, 25(9), 979987. https://doi.org/10.1016/j. technovation.2004.02.008

12. Galbreath, J., \& Galvin, P. (2008). Firm factors, industry structure and performance variation: New empirical evidence to a classic debate. Journal of Business Research, 61(2), 109-117. https://doi. org/10.1016/j.jbusres.2007.06.009

13. Gefen, D., Straub, D., \& Boudreau, M. (2000). Structural Equation Modeling Techniques and Regression: Guidelines for Research Practice. Communications of the Association for Information Systems, 7(7), 1-78.

14. Hair Jr, J., Sarstedt, M., Hopkins, L., \& G. Kuppelwieser, V. (2014). Partial least squares structural equation modeling (PLS-SEM). European Business Review, 26(2), 106-121. https://doi.org/10.1108/EBR-102013-0128

15. Hall, R. (1992). The strategic analysis of intangible resources. Strategic Management Journal, 13, 135-144. Retrieved from http:// dx.doi.org/10.1002/smj.4250130205

16. HassabElnaby, H. R., Hwang, W., \& Vonderembse, M. A. (2012). The impact of ERP implementation on organizational capabilities and firm performance. Benchmarking: An International Journal, 19(4), 618-633. https://doi. org/10.1108/14635771211258043

17. Lippman, S. A., \& Rumelt, R. P. (2003). A bargaining perspective on resource advantage. Strategic Management Journal, 24(11), 10691086. doi: 10.1002/smj.345

18. Makhija, M. (2003). Comparing the resource-based and market- based views of the firm: Empirical evidence from Czech privatization. Strategic Management Journal, 24(October 2002), 433-451. https:// doi.org/10.1002/smj.304

19. Majlis Inovasi Negara. (2007). National Innovation Model, Malaysia.

20. Mustapha, B. R., \& Abdullah, A. (2004). Malaysia Transitions Toward a Knowledge- Based. The Journal of Technology Studies, (Hr D), 51-61.

21. Muhammad, N. M. N., \& Ismail, M. K. A. (2009). Intellectual Capital Efficiency and Firm's Performance : Study on Malaysian Financial Sectors. International Journal of Economics and Finance, 1(2), 206-212.

22. Meulbroek, L. K. (2002). Integrated Risk Management for the Firm: A Senior Manager's Guide. Journal of Applied Corporate \& Finance, 14, 56-70. https://doi.org/10.2139/ ssrn. 301331

23. Osman, J. (2014). An Empirical Investigation into the Significance of Intellectual Capital and Strategic Orientations on Innovation Capability and Firm Performance in Malaysian Information and Communications Technology (ICT) Small-to-Medium Enterprises (SME).

24. Powell, T. C., and Dent-Micallef. (1997). Information Techonology as Competitive Advantage: The Role of Human, Business and Techonology Resources. Strategic Management Journal, 375-405.

25. Powell, T. C. (2001). Competitive advantage: Logical and philosophical considerations. Strategic Management Journal, 23, 873-880.

26. Saunders, M., Lewis, P., \& Thornhill, A. (2009). Research Methods for Business Students (5th ed.). Financial Times Prentice Hall.

27. Sekaran, U. (2013). Research methods for business: a skillbuilding approach (6th ed.). Chichester: Wiley. 